\title{
INFORMAL LEARNING EXERCISE FOR TIC PROFESSIONALS: A STUDY AT THE SUPERIOR MILITARY COURT
}

\section{ANTONELLA DONATO}

Master's Degree in Knowledge Management and Information Technology from the Department MGCTI at the Universidade Católica de Brasília (UCB).

System Analyst for the Office of Information Technology Projects at the Superior Military Court. Quadra 01 Edifício-Sede STM, Bloco B, Asa Sul, Brasília - DF - Brasil - CEP 70098-900

E-mail: antonella@stm.jus.br

\section{HELGA CRISTINA HEDLER}

Doctor in Organizational, Work and Social Psychology from the Department of Psychology at the Universidade de Brasília (UnB).

Professor for the Department of Knowledge Management and Information Technology Master at the Universidade Católica de Brasília (UCB).

SGAN 916 Módulo B, Sala A-114A, Asa Norte, Brasília - DF - Brasil - CEP 70790-160

E-mail: helgachedler@gmail.com

\section{FRANCISCO ANTONIO COELHO JUNIOR}

Doctor in Organizational, Work and Social Psychology from the Department of Psychology at the Universidade de Brasília (UnB).

Professor for the Department of Administration and Post-Graduate Program in Administration at the Universidade de Brasília (UnB).

Campus Universitário Darcy Ribeiro, Asa Norte, Brasília - DF - Brasil - CEP 70910-900

E-mail: acoelho@unb.br 


\section{ABSTRACT}

Purpose: Describe the informal learning strategies used by the IT and Communication professionals (TIC) of the Superior Military Court (STM), discussing their importance for professional development and labor skills related to the maximization of the results of human performance.

Originality/gap/relevance/implications: The research proved the differences in the use of the learning strategies among the TIC professionals and made it possible to capture the meaning of informal learning by professionals.

Key methodology aspects: The mixed methodology was applied and a questionnaire was created based on the studies of Camillis and Antonello (2010), Antonello (2011b), Pantoja and Borges-Andrade (2009), Lohman (2009), Berg and Chyung (2008) and Cunningham and Hillier (2013). Descriptive statistical analyses for quantitative data and thematic and categorical analyses were made for the content of the open answers. Summary of key results: Five categories of informal learning were identified: interpersonal relationships; work practices; sharing knowledge; unsystematic training and autonomous. Informal learning depends on: 1. interpersonal relationships, 2. plan for work practices, 3. sharing the knowledge, and 4. autodidactism. Some factors were considered facilitators and/or inhibitors and favorable and/or unfavorable to informal learning.

Key considerations/conclusion: The professionals describe informal learning as something difficult to prove and that the same thing happens through practice and the exercise of their skills. For future research, it was suggested the following: 1. analyze the influence of environment variables when employing the use of informal strategies of learning; 2. relate the learning of TIC professionals to the initiatives of knowledge management in the Organization; and 3. observe the role of leadership in the process of informal learning among professionals. 


\section{KEYWORDS}

Informal learning. Brazilian public sector. TIC professionals. Superior military court. Learning strategies.

\section{INTRODUCTION}

Since 1995, attempts to improve public management, via professionalization, have been observed. Management projects have been developed, such as the initiative by the Brazilian Federal Government to create The National Public Management and Simplification Program - GesPública (Decreto n. 5.378, 2005) and the publication of the Model of Excellency of Public Management (MEGP) (Ministério do Planejamento, Desenvolvimento e Gestão, 2013). Besides these, one can verify diverse initiatives to enhance personnel management and modernize public management in the strategy plans of the executive, legislative and judicial branches (Conselho Nacional de Justiça, 2009; Superior Tribunal Militar, 2011; Ministério do Planejamento, Desenvolvimento e Gestão, 2012).

These facts have helped Brazilian public management to become more oriented to results, to its real mission of fulfilling the collective demands of community. For example, the professionalism of the judicial routines has helped the public to have access to the transference of knowledge, greater transparency and social contact.

This can be seen in the Court where this research was carried out, the Superior Military Court (STM), the highest court of the Military Justice Department of Brazil (JMU). In its current strategy plan, JMU stated its concern over the modernization and improvement of judgmental activity, as well as the improvement of personnel management (Superior Tribunal Militar, 2012). In this sense, there is an initiative to "elaborate and implement the Program of Qualification and Training for the Military Justice Department of Brazil" (Superior Tribunal Militar, 2012, p. 51), in order to develop skills, knowledge, capabilities and behaviors of judges and employees. Based on this initiative, JMU offers various formal training programs for its officials.

In the context of professionalization, training action has contributed tremendously to the maximization of organizational results. The individuals in an organization are challenged to learn continuously through formal and 
informal methods. Fenwick (2008), García-Peñalvo and Conde (2014) and Alfieri, Brooks, Aldrich and Tenenbaum (2011) affirm that more and more organizations are concentrating on the push for informal learning and consider their formal training programs as just one of the possible tools for learning. According to Watkins and Marsick (1992), informal learning can also occur through formally structured experiences. In this case, the organizational support is paramount to the promotion of the so-called organizational learning.

Wang and Ahmed (2003) point out that management practices which motivate informal acts of learning in the workplace should take into account a wide range of variables, like organizational strategy, culture, structure, the ability to absorb that training action in formal work routines, besides the effort to solve problems and the participation of individuals and leadership, among others.

In this context, the assistance from colleagues is priceless (Barnett, 2012). The variable "support for informal learning at the workplace" concerns the analysis of perception, by the individual, of the psychosocial support from peers, colleagues and leaders in the learning process related to work tasks (Coelho \& Mourão, 2011). This support needs to be perceived in an explicit and unconditional manner by the individual, investing in some informal learning process (Coelho, 2009).

In the area of organizations in general, besides the challenge of constant learning, it is important to notice the strategic role of Information and Communication Technology (TIC), which supports the organizational processes and the management of organization (Ono \& Binder, 2010).

TICs are also increasingly integrated into daily governmental and social activities. Public administration constantly needs to improve public services, making them more accessible and citizen-friendly, as well as modernizing norms. TIC enables the optimization of internal processes, aids in the management and organization of operational and strategic information, qualifying the decision-making process and broadening access to services and information (Ministério do Planejamento, Desenvolvimento e Gestão, 2012).

At the same time, according to Hew and Cheung (2014), Hann and Caputo (2012) and Fenwick (2008), few studies have investigated the characteristics of IT professionals (Abreu, 2013; Ramos \& Jóia, 2014), their work areas and how such factors may influence their participation in informal learning activities (Lohman, 2009). No empirical studies were located which reported the use of informal learning strategies by IT professionals, within the Brazilian public administration. According to the studies of Holman, Epitropaki and Fernie (2001), diversified samples (as these proposed 
in this empirical study) are recommended to better comprehend the association between informal learning strategies and results, performance, knowledge assets qualitative differences within the comprehension of knowledge and the generation of innovation in formal organizations of the workplace (not only in the school context, in the presence of students).

Regarding the characteristics of IT professionals, Abreu (2013) mapped the values of workers in the Brazilian software and IT services. She discovered that their axiological labor priorities were professional fulfillment, stability and social relationships. Ramos and Jóia (2014) pointed out that businesses should create strategies to maintain these professionals, since they seek opportunities for career-growth, beyond the technical skills, together with subjects that do not follow a routine.

IT professionals are motivated by career anchors (Crepeau, Crook, Goslar, \& McMurtrey, 1992), based on the idea of being able to work with autonomy, creativity, continuous development of technical and management skills, as well as the potential of developing the notion of organizational identity and work stability (Abreu, 2013).

When focusing upon informal learning in the area of literature (Berg \& Chyung, 2008; Lohman, 2009; Pantoja \& Borges-Andrade, 2009; Camilillis \& Antonello, 2010; Antonello, 2011b; Coelho \& Mourão, 2011; Cunningham \& Hillier, 2013; Inanc, Zhou, Gallie, Felstead, \& Green, 2015), it was seen that informal learning in the same professional category in public organizations, in different teams, had not yet been researched. This gap inspired this research: to describe the strategies of informal learning used among TIC and STM professionals. The research discusses the importance of informal learning for their professional development and the labor skills related to the maximization of results and human performance. The specific objectives were defined as follows: to identify 1 . the most widely used informal learning activities; 2 . the perception of informal learning; and 3. facilitating and inhibiting factors of this type of learning in the perception of the same, in relation to organization.

\section{LITERATURE REVIEW}

\subsection{International studies}

International literature (Ang \& Slaughter, 2000; Hoffman, 2003) on IT professionals has concentrated on the investigation of individual variables in the study of career perspectives. Hoffman (2013) identified growing 
unhappiness among IT professionals in regards to the organizations where they work and the opportunities of evolution in their careers. With a heavy workload, little training and a lack of confidence in their companies, the professionals are becoming unmotivated. Huarng (2001) identified emotionally exhaustive lifestyles among IT professional because of overworking, together with little autonomy and few opportunities for professional development. Mangia and Jóia (2015) and Ramos and Jóia (2014) investigated the professional profile of IT workers in relation to the transition of their careers to other functional areas. Such transitions have demanded quite heterogenic profiles in professional backgrounds, and have provoked exhaustion with the work in the IT field itself. Negative satisfaction was also identified in the routines of IT area in general, as well as the need to acquire new professional experiences to remain attractive to the job market, the need for professional growth and the constant search for acquiring skills and developing management.

Moura and Helal (2014) discussed conflicts regarding IT professional formation. Thus, there would be different variables able to impact in the area of this professional form, focusing on the aspects of personality, knowledge domain, participation of the professional in labor relationships of power and the continual search for self-rule in the profession. Lohman (2009) investigated three domains of informal learning in the workplace of IT professionals: 1. types of activities used for learning; 2 . characteristics of the workplace, which inhibit learning activities; and 3. personal characteristics, which increase motivation to become involved in learning activities.

Results showed that professionals use the Internet for research purposes to a great degree, to learn informally. When they are unable to solve some learning need with this activity, they resort to more interactive actions, such as conversing and sharing resources with others. They also shared six environmental factors inhibiting the involvement of informal learning activities: lack of time to become more acquainted with their co-workers, lack of space for meetings/work, lack of technological equipment, including inability to fellowship with co-workers and organizational not supportive culture.

Berg and Chyung (2008) investigated the facts and types of activities that influenced informal learning practiced by people at work. In addition, they analyzed the relation between engaging in informal learning, the presence of characteristics of learning organization and the factors that affect the engagement of perceived informal learning. The results indicated that the most used type of learning activity was "reflecting upon their knowledge and previous actions" and the least used type was "posting questions on discussion lists". 
It was also observed that there was greater frequency of participation in informal learning processes than in formal training programs, when those interviewed were required to learn something new to do certain work tasks. It was also verified that the culture of organizational learning was not a strong predictor for the degree of involvement of workers in activities of informal learning. As age, sex and the scholastic level did not impact the engagement of informal learning, because older workers also showed tendencies to become involved in informal learning activities. Concerning personal and environmental factors that influenced informal learning according to workers, the factor that most affected workers was "interest in their present professional field" and that affected least was "monetary rewards distributed as a reward for good performance".

Cunningham and Hillier (2013) investigated the characteristics and processes that improved informal learning in work environments in the public sector in Canada. The research sought to develop forms of enhancing a formal training program.

From interviews and questionnaires, examples concerning practices of informal learning were solicited for 40 supervisors experienced during their careers. Based on the extracted examples, seven underlying themes were defined. These themes describe the activities and processes of informal learning. The first three themes on the kinds of activities were learning relationships; learning opportunities that broadened or redesigned their jobs; and the enriching opportunities that provided higher levels of management learning. The four other themes describe the processes that facilitate informal learning: planning processes, active learning and modeling; relationship dynamics; and learning linked to applications.

\subsection{Theoretical background}

Regarding learning at the workplace, it cannot be supposed that the workplace is a unified environment or even a support/aid for all trainings (Tynjälä, 2008; Jacobs \& Park, 2009). Besides this, it is important to understand that each individual learns according to his/her own strategies. Holman et al. (2001) define the strategies as practices that people use to help acquire skills and abilities applied in work routines. Berings, Doornbos, and Simons (2006) and Sonnentag, Niessen, and Ohly (2004) refer them as informal practices that individuals use to acquire and apply fresh knowledge in their workplaces (Berings et al., 2006; Sonnentag et al., 2004).

The state of art regarding learning strategies, according to Le Clus (2011) and Manuti, Pastore, Scardigno, Giancaspro, and Morciano (2015), 
highlights the importance of analyzing human characteristics of trainings in relation to their own engagement in the process of informal learning at work. For example, there is research which links the frequency of the use of learning strategies to the acquisition and expression of professional and organizational skills (Brandão \& Borges-Andrade, 2011; Brandão, Borges-Andrade, Puente-Palacios, \& Laros, 2012) and organizational change and innovation (Isidro-Filho, Guimarães, Perin, \& Leung, 2013; Neiva \& Pantoja, 2011; Souza, 2016), among other themes.

According to the latest systematic reviews in the field of informal learning by Noe, Clarke, and Klein (2014), empirical studies about human characteristics related to the use of training strategies at the workplace, which can contribute positively to organizational results, has been the focus of organizational studies in empirical investigation of this variable.

\subsubsection{Types of learning at work}

Learning in organizational environments is usually associated to the processes of training, development and education (TD\&E) (Pantoja \& Borges-Andrade, 2009). Yet, not all situations that generate learning come from formal actions. Workers also learn from different points of view, developing skills and making choices based on focusing on their own interests (Conlon, 2004).

Abbad and Borges-Andrade (2004) characterize two types of learning in organizations: natural and induced. The natural type occurs informally by way of mechanisms, such as trial and error, imitation, observation, search for interpersonal help, search for written material and informal contacts with colleagues. The induced type would consist of actions of TD\&E oriented to tend to the specific necessities of work.

In literature, certain terms are constantly used, i.e. formal learning, non-formal, informal (Antonello, 2011b). However, in practice, it is impossible to notice the differences between the terms formal and non-formal. For this reason, Antonello (2011b) developed a taxonomy to deal with the learning forms: formal and informal.

In this research, we define formal and informal learning based on the analysis of studies of Coelho and Borges-Andrade (2008), Antonello (2011a), and Lohman (2009). Formal learning is planned, systemized and structured for a certain objective. It is offered in a formalized context of teaching by an institution that may or may not be the company where the intern works. It presents a specific type of knowledge/training, which is standardized and organized, targeting its acquisition and application in an easily reproduced form. 
Informal learning, however, happens naturally, as part of the daily work, being predominantly unstructured, experiential, and non-institutional (Casey, 2013; Booth, Carroll, Papaioannou, Sutton, \& Wong, 2009). It involves learning activities employed by workers at the workplace and result in the development of their knowledge banks and professional capabilities. Informal learning is situational; it results in activities related to work and may be incidental, intentional, or even planned.

\subsubsection{Learning as a social process}

According to De Grip (2015), Chan (2013), and Tynjälä (2008), individual and group learning on the job is a highly social activity which requires interaction and dialogue, requires the types of challenges that make learning necessary, and involves reflection about past experiences and the planning of future actions.

Beginning with the basic idea that it is the person and not the organization who learns, the social perspective of learning deals with understanding and helping individuals to learn inside the organizations (Eraut, 2007; Camillis \& Antonello, 2010).

We adopted the vision of Elkjaer (2001), who considered learning a part of a social practice that involves interpretation. This perspective is based on the social practice of the organizational life where processes and social structures are continually produced and reproduced, interpreted and re-interpreted.

Easterby-Smith and Araújo (2001) add the political element to the social perspective where knowledge is socially built by individuals and groups. The interpretive process inside organizations is directly measured by relationships of power, making it necessary that the conceptions of organizational learning take into consideration the political processes, which occur in organizational life.

\subsubsection{Experimental learning}

According to Tomkins and Ulus (2016), Roberts (2008) and Fenwick (2003), experiential learning is seen as a continuous reorganization and reconstruction of experiences, which occur constantly in every situation where people act and interact, reflect and think.

The theory of experiential learning formulated by Kolb (1984) defines learning by six characteristics: 1 . it is conceived as a process; 2 . it is a continuous process based on experience; 3 . it demands that the individual 
solves opposite dialectic demands; 4 . it is a holistic, systemic and integrative process; 5 . it involves interactions between people and environment; and 6 . results in the creation of knowledge.

The process of learning is analyzed as a cycle where the training experiences all the stages, experimenting (concrete experience), reflection (reflexive observation), thought (abstract concepts) and action (active experience) in a recurring process sensitive to the situation of learning and what is being learned (Baker, Jensen, \& Kolb, 2005).

Thus, experiential learning can be defined as "a process that begins with an experience followed by reflection, discussion, analysis and evaluation of the experience" (Antonello, 2011a, p. 143). In the words of Zundel (2012), not all routines result in learning, and learning would be, above all, mental. Besides this, a person would learn motivated by his/her own reasons, that is, he/she strives to obtain learning that makes sense to him/her, starting from demands or his/her own or intrinsic interests.

\section{METHOD}

An exploratory/descriptive survey was made at the Information Technology Directorate (Ditin) of STM, where TIC professionals work. To solve the problem, the mixed method was applied (Silva \& Menezes, 2005).

\subsection{Participants}

The universe of participants was comprised of 42 employees of Ditin, excluding temporary workers, employees loaned by other organizations, trainings and service help. This criterion was adopted intentionally due to the fact that not all knew the specific characteristics of the Department being studied.

The Ditin is divided into three coordinating departments: Service Coordination (Caten), with five employees, Technology Coordination (Cotec), with 14 employees and Systems Coordination (Cosis), with 23. Each coordination has a different team, since TIC activities vary in complexity, amplitude and range.

Out of the 42 people invited to participate in the research, the final sample was 39 employees: five (13\%) from Caten, 13 (33\%) from Cotec and $21(54 \%)$ from Cosis. Out of these, nine (23\%) are women and $30(77 \%)$ are men. 
In addition, $20(51 \%)$ are judiciary technicians and nine (49\%) are analysts. As regards to educational background, three $(8 \%)$ hold a master degree; 18 (46\%) hold a specialization degree; 15 (38\%) hold a bachelor degree; and three (8\%) have completed the high school. Concerning age, four (10\%) are between 18 and 29 years old; 15 (39\%) between 30 and 39; $13(33 \%)$ between 40 and 49; six (15\%) between 50 and 59; and only one $(3 \%)$ is 60 or over.

Most of participants have more than 10 years of service in STM. Six (15\%) have less than one year of service in STM; eight $(21 \%)$ have one to five years of service; three (8\%) have six to 10 years of service; $11(28 \%)$ have between 11 and 15 years of service; 5 (13\%) have 16 to 20 years of service; $4(10 \%)$ have 21 to 25 years of service; and 2 are over 26 years of service.

\subsection{Data instrument collection}

From the readings of Camillis and Antonello (2010), Antonello (2011b), Pantoja and Borges-Andrade (2009), Lohman, (2009), Berg and Chyung (2008) and Cunningham and Hillier (2013), examples and definitions of learning strategies were located, as well as influencing factors (facilitators or inhibitors) of learning. From these, the topics were created and/or adapted to the activities of TIC professionals.

Two situations were constructed, the first for learning strategies and the second for learning influencers. The learning strategies were grouped into six categories: 1. participate in formal learning activities, 2. learn alone, 3. interact with people, 4 . obtain information, 5. perform practical work activities, and 6 . experience activities outside the workplace. Each category is made up of one series of activity items.

For the learning influencing factors, contextual and individual factors were identified and were applicable to the STM reality. Such factors were analyzed and grouped into five themes: 1 . organization of work, 2. rewards, 3. communication, 4. individual characteristics, and 5. work environment. Each category consists of a series of influential factors.

The questionnaire comprised of four sections: 1 . characteristics of respondents, with six socio-demographic questions; 2 . perception of informal on-the-job learning, containing two open questions; 3. learning activities at the workplace, with 33 items to be answered in a scale of frequency, like "Likert", with five points; and 4. informal learning influencing factors at the workplace, with 13 items that could be labeled Inhibitor or Facilitator. At the end, two open questions were presented about other different facilitators and/or inhibitors of learning the participant would like to mention. 


\subsection{Procedure for collection and data analysis}

After authorization to carry out the survey was obtained, the questionnaire, which was printed to be answered in pencil, was handed out individually and turned in later. The collection took around 20 days during the month of November 2013. The answers were transferred to electronic form for analysis.

Descriptive statistics were used for numerical data and the analysis of thematic categorical content according to Bardin (2011) for open questions. All themes and categories were submitted to two examiners for semantic analysis.

The analysis stages were:

- identification of informal learning activities used to a lesser or greater degree by all TIC professionals and by the coordination; and among the influencing factors, the facilitators and inhibitors mentioned to a lesser or greater degree by TIC professionals and by the coordination;

- thematic analysis of learning activities used by TIC professionals and other learning facilitators and inhibitors; and

- categorical thematic analysis regarding the perception of informal learning by IT professionals.

\section{RESULTS AND DISCUSSIONS}

The results were presented in the general context of Ditin, highlighting the differences between the teams (coordination), if any. At Ditin, 63\% of respondents participated in the formal training programs financed by STM; $57 \%$ participated in formal training sessions of personal interest and were not proposed by STM; and 55\% also participated in formal training sessions not financed by STM.

The most commonly used formal strategies were the following: 1. learn from one's own errors and/or trails and errors; 2. research on the Web (internet/intranet); 3. alone, concerning one's knowledge, experiences and previous actions; 4 . speak face to face with other co-workers under the same coordination, to solve problems; and 5. self-analysis, identifying one's own strengths and weaknesses to achieve a goal/objective. It can be observed that strategies 1 and 4 were also identified by Lohman (2009) in a study on informal learning by IT professionals. 
The least used strategies were: 1 . participate in practice communities; 2. share questions in lists/forums of discussion; 3. participate in social projects; 4 . interact with people from different areas of STM, except IT, to solve problems; and 5. act as a mentor, helping other co-workers.

The most ten informal learning activities used in the three coordinations were: search for information on the Web (internet/intranet); learn from one's own errors and/or trials and errors; reflect, alone, on one's knowledge, experiences and previous actions; speak face to face with other co-workers under the same coordination, to solve problems; self-analysis, identifying one's own strengths and weaknesses to achieve a goal/objective; speak face to face with one's superior hierarchy, to solve problems; and read magazines, newspapers, articles and/or specialized books.

These results point to what Manuti et al. (2015) and Coelho and Mourão (2011) described in terms of the importance of self-teaching and the support of colleagues and friends for the acquisition and expression of new work skills. The context of learning, according to Isidro et al. (2013), is paramount to the informal development of these skills.

Among the five least used of the three coordinations, it can be seen that the activity "participate in practice communities" is the only one common to all, which can be explained by the non-existence of practice communities in the STM. This finding goes along with what Le Clus (2001) verified in relation to organizations, which need to invest more in practice communities, rarely used by the same.

Comparing the most and the least activities used by the teams, it can be observed that the activity "research experiences and solutions in lists/ forums of discussion" is one of the most widely used by Cosis, and one of the least used by Caten.

On the other hand, the activity "receive information from suppliers or specialists/consultants contracted to solve problems" is one of the least used by Cosis, but one of the most used by Cotec. This might be explained by greater concentration of contracts with suppliers and specialists/consultants by Cotec.

In relation to the activities of informal learning, some differences among the coordinations can be noticed. This shows that, within each specialty of IT professionals, there might be differences in the usage of one or another practice. Thus, one can see the need not to generalize the use of learning practices among the TIC professional in the organization. This conclusion is in agreement with Inanc et al. (2015) and Abbad and Borges-Andrade (2004), who state that learning occurs on an individual level, resulting also from its interaction with the context; and with García-Peñalvo and Conde (2014) 
and Antonello (2011b) who concluded that learning occurs because of an activity, the context and the culture in which it is situated.

\subsection{Influential factors}

At Ditin, the facilitating factors for informal learning most frequently mentioned were the following: 1 . physical closeness to co-workers; 2 . relationships with co-workers; 3 . unlimited access to the Internet; 4. communication flow between peers; and 5. current area of work, together with one's personal characteristics. Such factors are similar to those found by Eraut (2007) and Cunningham and Hillier (2013), with focus on variables in the context of labor and their influence on the incidence of informal learning.

The most frequently mentioned inhibiting factors were the following: 1. remuneration structure (career and jobs); 2 . physical structure of the workplace; 3 . flow of communication with superior hierarchians; 4 . manner in which the work is organized (structure and formal division of organizational units, skills and attributes and formal division of the organizational units, skills and attributes), together with current developed activities; and 5. performance of superior hierarchians. These factors agree with those reported by Conlon (2004) and Hew and Cheung (2014) concerning the identification of barriers to informal learning at the workplace.

The difference in the size of the sample of each coordination should be considered in future analyses, because what could be a facilitator/inhibitor for one coordinating body might not present the same result when analyzed in a broader form. In replications of this study, it would be wise to take this methodological care.

The way in which the work is organized (structure and formal division of organizational units, skills and attributes) is a strong facilitator for the Caten team, where $100 \%$ judged it so. At Ditin as a whole, $71.79 \%$ identified it as a facilitator. The organization of work was suggested by Souza (2016), Neiva and Pantoja (2011) and Watkins and Marsick (1992) as being a condition for the work of individuals in informal learning actions at work.

\subsection{Other learning activities}

The thematic analysis of the question "Are you engaged in some other learning activity which was not previously described? Which one?", pointed to non-described themes in this research, such as, online and free university courses; academic courses; university course via distance learning; autono- 
mous activities; hobbies; source code readings; participation in seminars about personal development; and watching videos on the web.

In relation to other activities of learning used by IT professionals, it can be seen that the internet is an aid to learning, as it was discovered that professionals were participating in courses and watching videos on the network.

Such results agreed with Mangia and Jóia (2015) and Lohman (2009), who verified that TIC professionals heavily use research on the internetto learn. It was also highlighted as a source of learning the professional participation in other areas and hobbies, in agreement with the research of Antonello (2011b). Besides these, consulting other types of work, in this case, source codes, was mentioned, showing the importance of access and sharing of information. Formal learning was also stressed, such as academic courses. Finally, the search for personal development was considered as a source of learning, according to Antonello (2011b).

\subsection{Perception of factors that influence learning}

The perception of other factors that facilitate and inhibit learning were graphic in relation to frequency, after synthesis of the answers.

\section{(Graph 1)}

\section{INFORMAL LEARNING FACILITATORS}

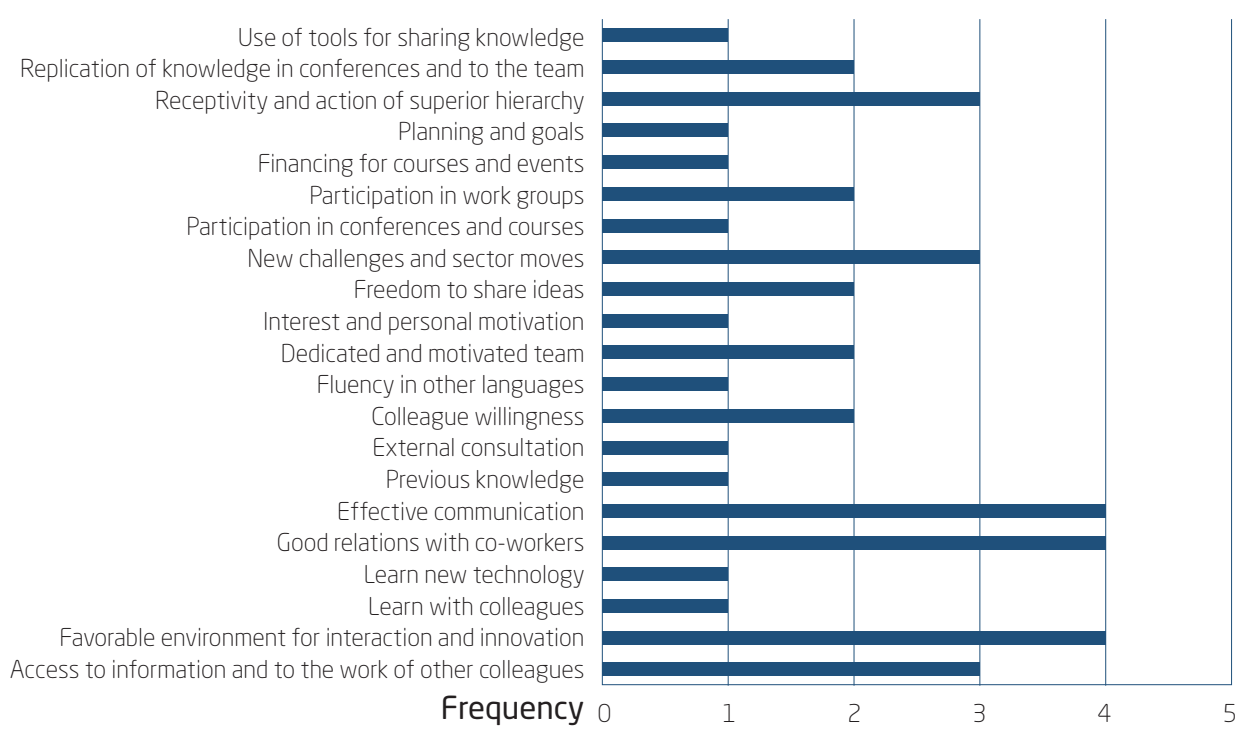

Source: Elaborated by the authors. 
Facilitators can be inputs for the purpose and application of practices, as for example, the usage of tools for sharing knowledge, replication of knowledge acquired in conferences and courses for the rest of the team, and the use of work groups.

\section{(chart 2)}

\section{INHIBITORS OF INFORMAL LEARNING}

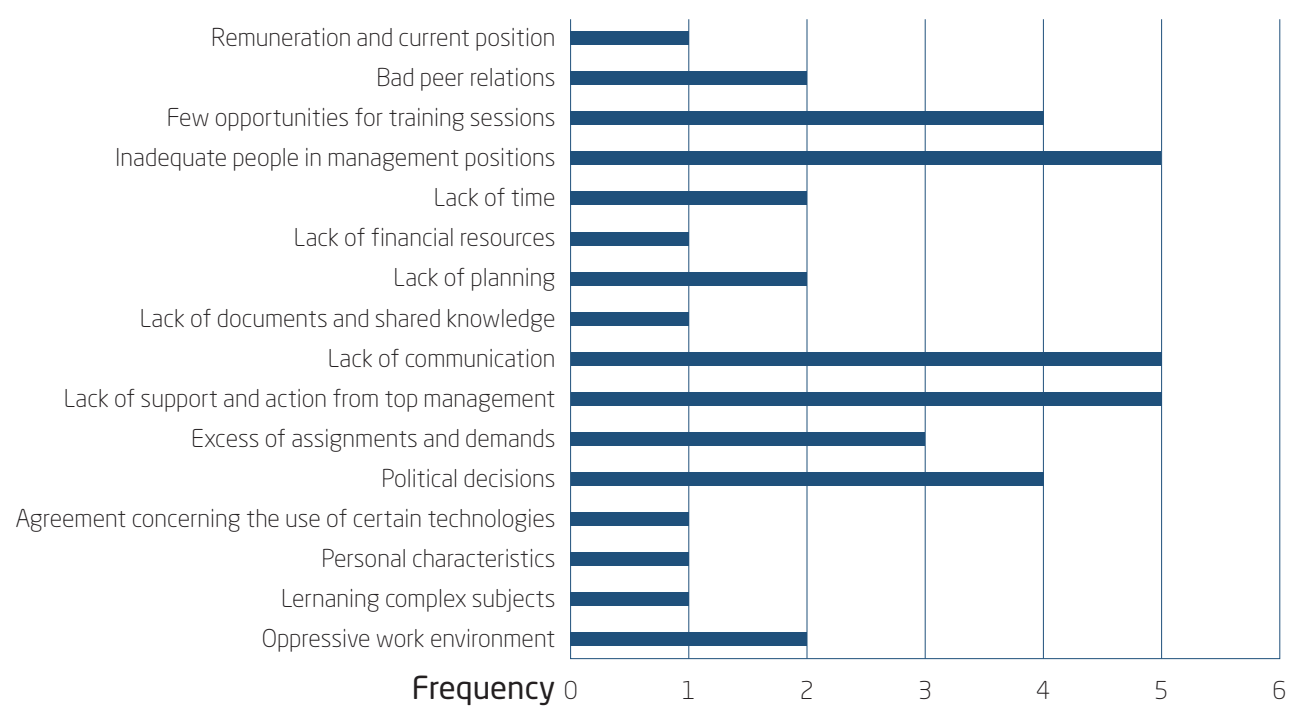

Source: Elaborated by the authors.

Among the identified factors, one can observe some inter-relationships. For example, excess of assignments and demands; lack of communication, time and planning; oppressive work environment; management by inadequate people; and even the misuse of certain technologies, can be related to the themes of lack of support and action on the part of the superior hierarchy and top management. These factors, according to Manuti et al. (2015), Noe et al. (2014), and Cunnigham and Hillier (2013), are conditioners for inaction of learning at work. Themes related to colleagues, communication and access to information were highlighted, even though already figured in the structured section of the research. This fact can indicate the relevance of factors as influencers of learning.

The importance of psychosocial support was also observed, as suggested by Coelho and Mourão (2011), since the participants also identified the importance of relationships between colleagues and bosses as being influen- 
tial to learning. Phrases, such as, how "Archaic administration is more based on politics than on the objectives of organization/clients" and "Political decisions that determine the choice of a technology less appropriate for the work situation, despite the evaluation of the responsible technicians" point out that politics is a learning inhibitor.

\subsection{Perception of informal learning}

Informal learning is characterized by the following categories: interpersonal relationships; work practices; sharing of knowledge; unsystematic training and autonomy. We illustrated the categories at the top of the figure below, with the order of the themes according to their frequency indicated within parentheses, and the respective examples.

\section{(Figure 1)}

\section{INTERPERSONAL RELATIONSHIPS CATEGORY}

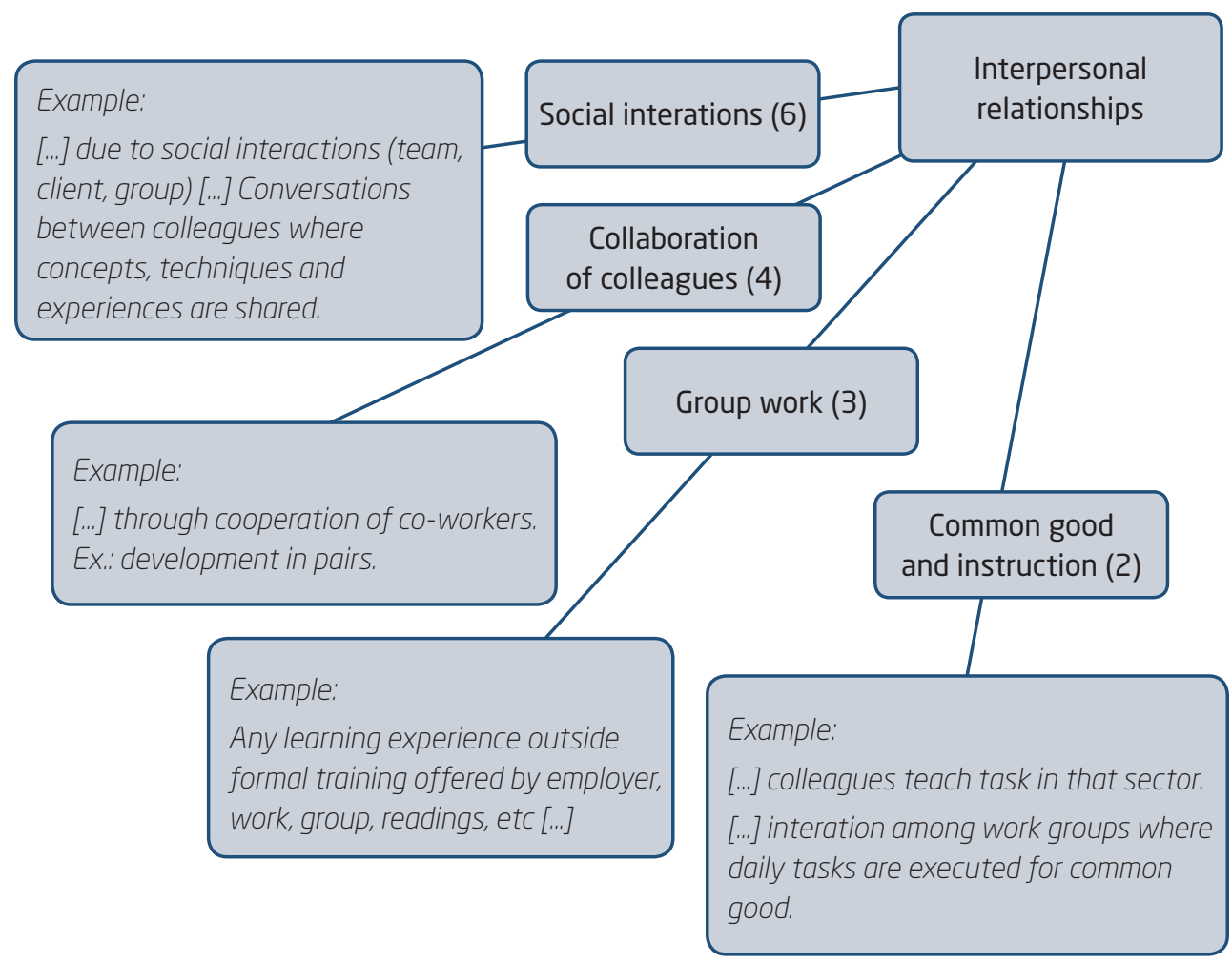


Social interactions between colleagues, work in groups, the execution of activities for a common good, are elements that enable interpersonal relationships to become sources of informal learning. They are even considered a priceless source of the construction of meaning and identity regarding the task (Ono \& Binder, 2010).

\section{(Figure 2)}

\section{PRACTICES AT WORK CATEGORY}

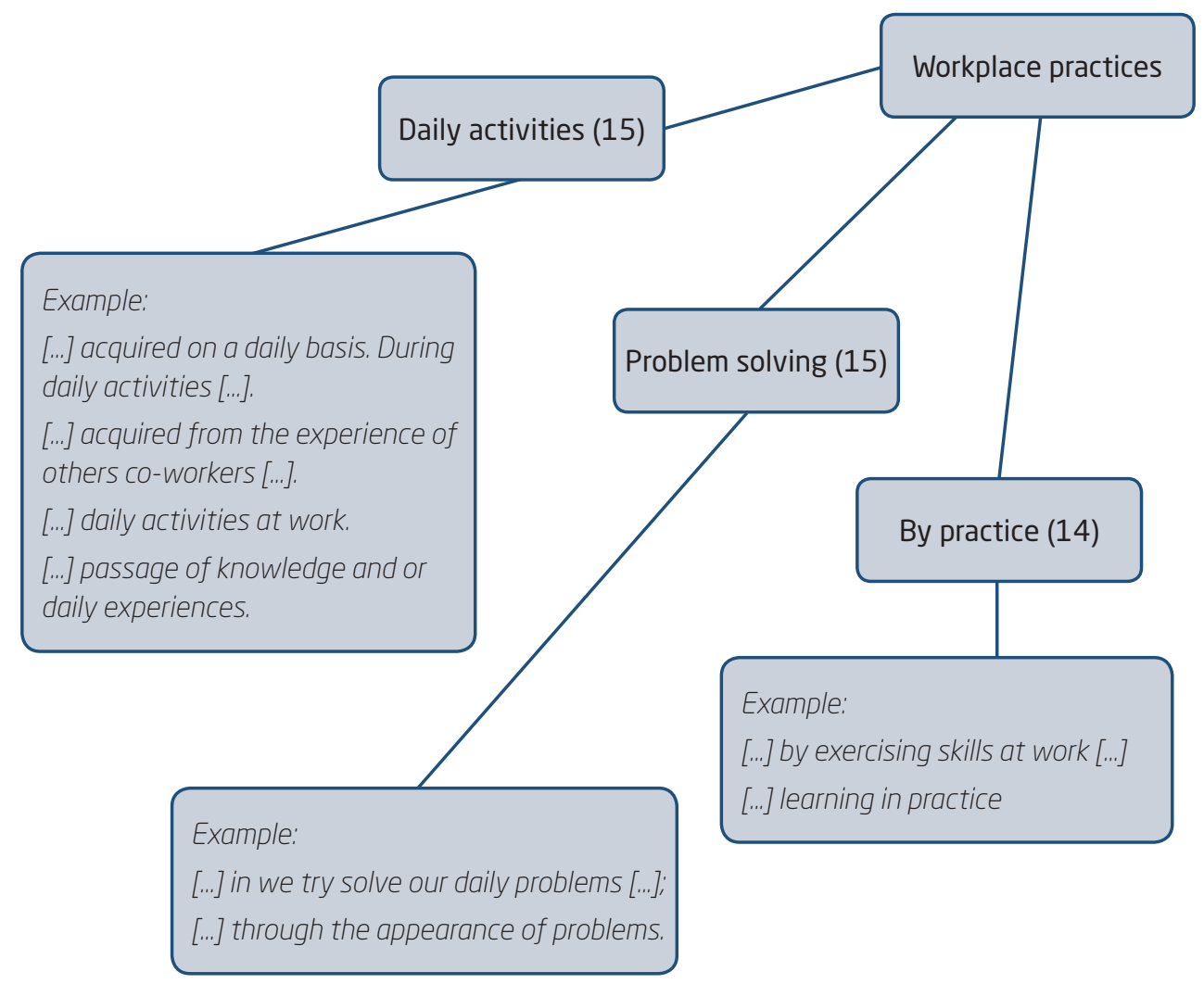

Source: Elaborated by the authors.

Work environment practices, involving daily activities, the solution of problems are sources of informal learning. In other words, informal learning can appear through unexpected means from daily activities, although their perception may sometimes not be very clear or is mixed with other types of experience, such as skills. 


\section{(Figure 3)}

\section{SHARING OF KNOWLEDGE CATEGORY}

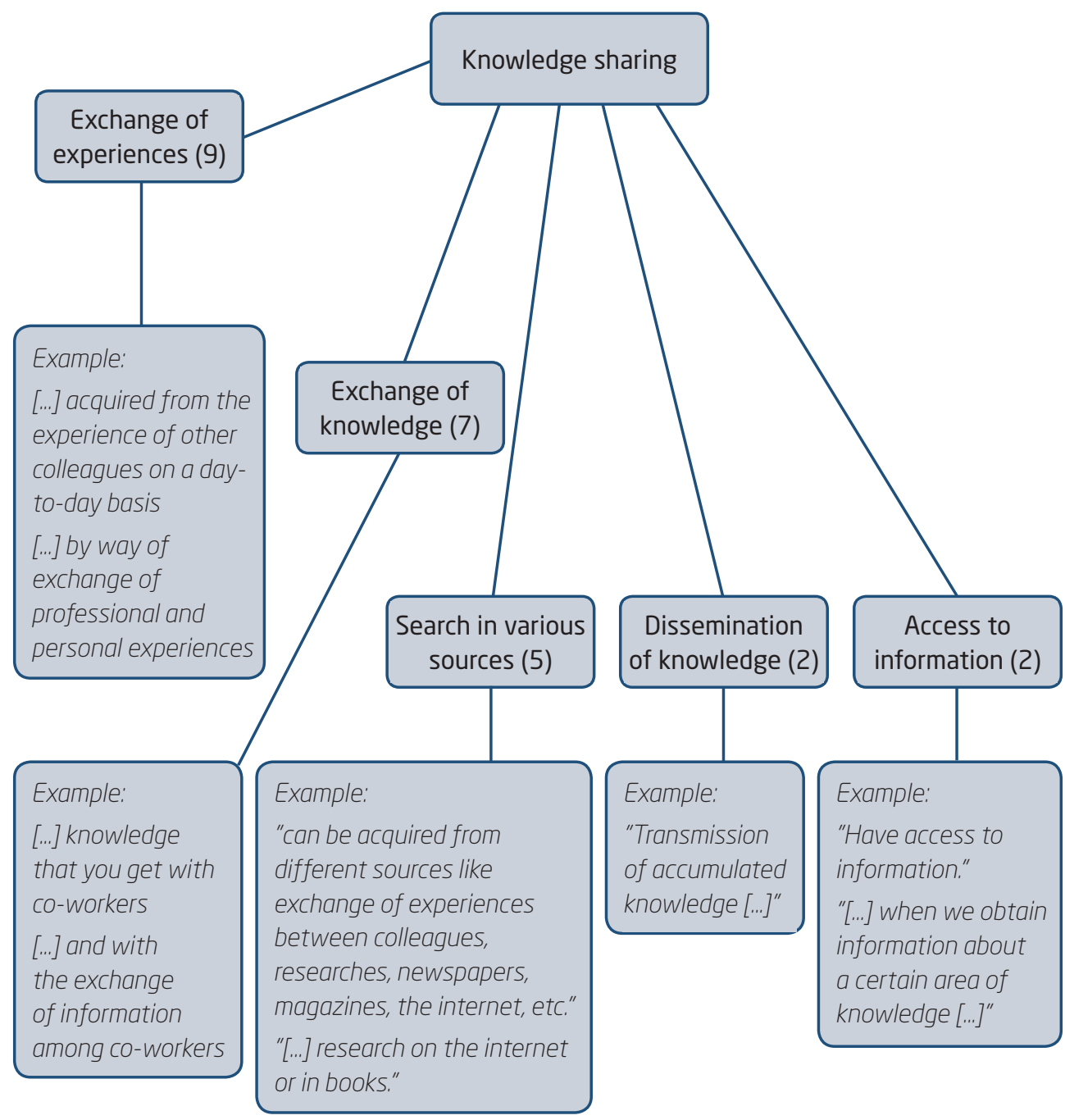

Source: Elaborated by the authors.

The exchange of experiences and knowledge, as well as the search for and access to information, permits the sharing of knowledge and consequently, learning. 


\section{(Figure 4) \\ UNSYSTEMATIC TRAINING CATEGORY}

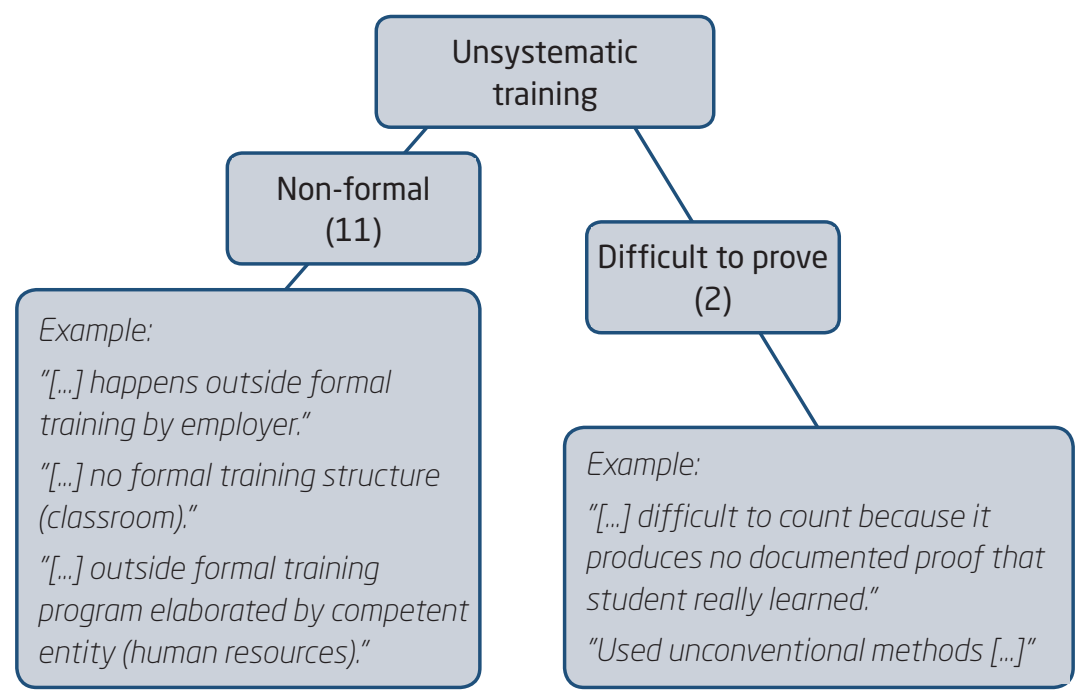

Source: Elaborated by the authors.

\section{(Figure 5)}

\section{AUTONOMOUS CATEGORY}

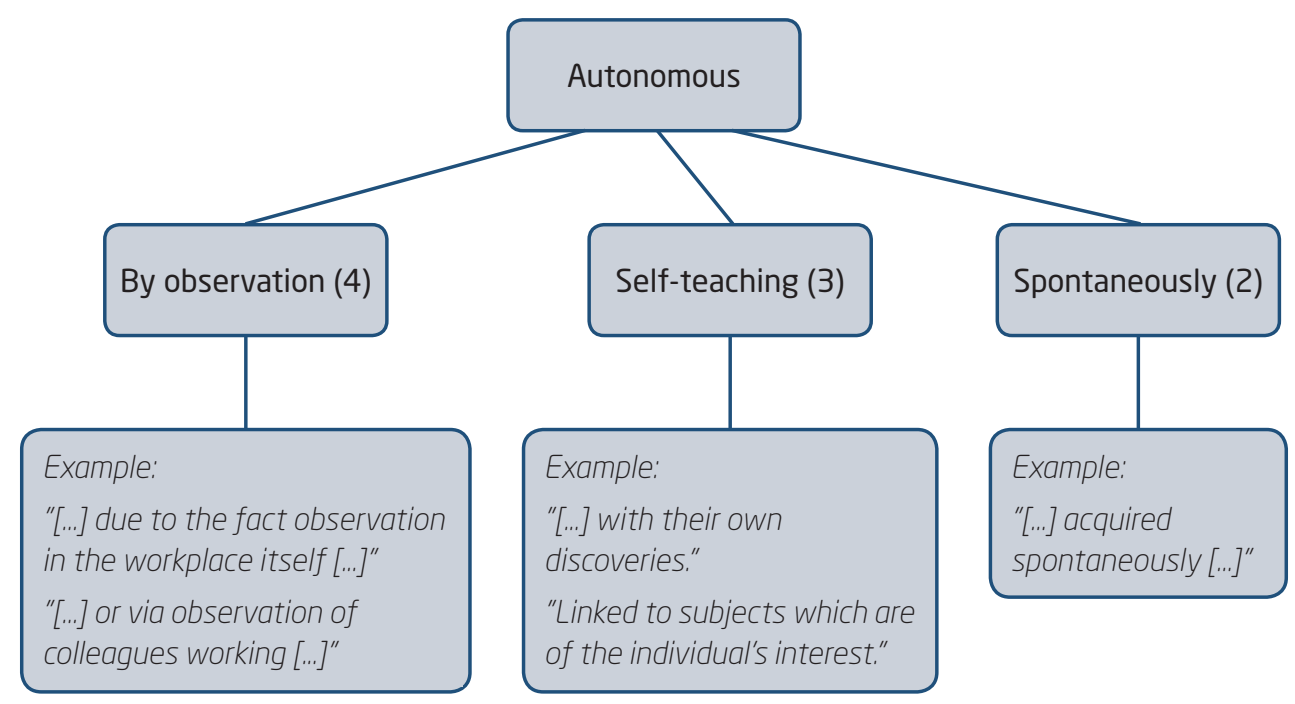

Source: Elaborated by the authors. 
Informal learning was considered autonomous because it was accomplished by individual and spontaneous practices.

Based on the results, in relation to perception regarding informal learning, it can be concluded that TIC professionals understand what informal learning is and perceive that it exists. According to professionals, informal learning happens through interpersonal relationships, work practices, sharing of knowledge, and unsystematic autonomous training.

\section{FINAL CONSIDERATIONS}

The purpose of this study was to describe the strategies of informal learning used among TIC professionals of STM, highlighting its importance for professional development and the labor skills related to the maximization of results and human performance. It also purported to highlight the facilitators and inhibitors of individual learning.

Considering the nature of activities developed by IT professionals, results pointed to the use of different learning strategies in the workplace. The role of self-teaching deserves attention. Factors related to the psychosocial support, the acquisition and expression of skills by colleagues were the main conditioners identified as influencers of informal learning in the workplace.

It is expected that the results of this research can be the object of the proposition of actions to promote informal learning, permitting the accumulation and distribution of relevant information in the workplace - for those involved in the learning process and for the organization.

In relation to the use of informal learning strategies, some differences between the coordinations were observed, demonstrating that, within each specialty of TIC professionals, there may be differences in the use of one practice or another. Thus, it is valid not to generalize the use of learning practices among the professionals of the organization, since, given that components of the organizational structure of the department might foster, to a greater or lesser degree, the need to acquire and express certain professional work skills. It was possible to bring up other forms of learning, besides those proposed in the research - among these, the internet.

As a source of learning, professional action in other areas was identified, as well as hobbies outside the organizational setting. Besides this, the search for personal development was considered a learning strategy, highlighting 
the importance of self-knowledge and the involvement of informal actions outside the planned context of skills and training.

Other facilitating and inhibiting learning factors besides the proposals in the research instrument were stressed. The importance of psychosocial support for the influential factors on learning was seen, since the impact of relationships between colleagues and bosses was also observed. Politics was also stressed as an element that inhibited learning.

In relation to the perception of informal learning, professionals understand what informal learning is and perceive its existence. Informal learning was described as being difficult to prove and put into practice via the exercise of skills.

Finally, it may be suggested that politics and organizational practices could be repositioned, taking into account the results displayed here, reinforcing that it is already working and perfecting what it might be needed.

\section{LIMITATIONS AND FUTURE STUDIES}

Concerning the instrument of research, the block of facilitators or inhibitors to learning, it was seen fit to include the "neutral" option, because some participants left some items unmarked, which could indicate a neutral factor, as facilitators or inhibitors to learning.

A suggestion for future research would be to validate psychometrically the measurement constructed here. In addition, it would be recommendable to identify how the influence of environmental variables occurs when employing informal learning strategies, relating, for example, time of service in the organization, styles of leadership and the size of command with the greatest or least effort to the undertaking of training actions in the workplace.

It would also be recommendable to link the learning of TIC professionals to initiatives of knowledge management in the organization, since the consultation of other works, as in the case of developed source codes, also was observed. Since it was verified that the three most inhibiting factors cited were the lack of support from the superior hierarchy and top leadership, the lack of communication and the management of inadequate people, future research could study the role of leadership in the process of informal learning among professionals. 


\section{) APRENDIZAGEM INFORMAL DE PROFISSIONAIS DE TIC: UM ESTUDO NO SUPERIOR TRIBUNAL MILITAR}

\section{RESUMO}

Objetivo: Descrever as estratégias de aprendizagem informal utilizadas entre os profissionais de tecnologia da informação e comunicação (TIC) do Superior Tribunal Militar (STM), problematizando a sua importância para seu desenvolvimento profissional e das competências laborais relacionadas à maximização dos resultados e desempenho humano.

Originalidade/lacuna/relevância/implicações: A pesquisa evidenciou as diferenças na utilização de estratégias de aprendizagem entre os profissionais de TIC e possibilitou captar o significado de aprendizagem informal pelos profissionais.

Principais aspectos metodológicos: Utilizou-se o método misto, com a criação de um questionário fundamentado nos estudos de Camillis e Antonello (2010), Antonello (2011b), Pantoja e Borges-Andrade (2009), Lohman (2009), Berg e Chyung (2008) e Cunningham e Hillier (2013). Foram realizadas análises estatísticas descritivas para os dados quantitativos, temática e categorial para o conteúdo das respostas abertas.

Síntese dos principais resultados: Identificaram-se cinco categorias de aprendizagem informal: relacionamentos interpessoais; práticas no trabalho; compartilhamento de conhecimento; capacitação assistemática e a categoria autônoma. A aprendizagem informal depende do seguinte: 1. relacionamentos interpessoais, 2 . desenho das práticas no trabalho, 3. compartilhamento de conhecimento e 4. autodidatismo. Alguns fatores foram considerados facilitadores e/ou inibidores, e favoráveis e/ou desfavoráveis à aprendizagem informal.

Principais considerações/conclusões: Os profissionais descrevem a aprendizagem informal como de difícil comprovação e que a mesma ocorre por meio da prática e do exercício de suas competências. Sugere-se para trabalhos futuros: 1. analisar a influência de variáveis ambientais no uso das estratégias informais de aprendizagem; 2. relacionar a aprendizagem dos profissionais de TIC com as iniciativas de gestão do conhecimento no Órgão; e 3. observar o papel da liderança no processo de aprendizagem informal dos profissionais. 


\section{PALAVRAS-CHAVE}

Aprendizagem informal. Setor público brasileiro. Profissionais de TIC. Superior tribunal militar. Estratégias de aprendizagem.

\section{EL APRENDIZAJE INFORMAL PROFESIONALES DE LAS TIC: UN ESTUDIO EN EL TRIBUNAL SUPERIOR MILITAR}

\section{RESUMEN}

Objetivo: Describir las estrategias de aprendizaje informales utilizados por los profesionales de tecnología de la información y la comunicación (TIC) del Tribunal Superior Militar (TSM) discutiendo su importancia para su desarrollo y habilidades de trabajo profesionales relacionados con la maximización de los resultados y el rendimiento humano.

Originalidad/laguna/relevancia/implicaciones: Destacó las diferencias en el uso de estrategias de aprendizaje entre los profesionales de TIC. Fue posible captar el significado del aprendizaje informal para los profesionales.

Principales aspectos metodológicos: Se utilizó el método mixto, fue creado un cuestionario basado en estudios de Camillis y Antonello (2010), Antonello (2011b), Pantoja y Borges-Andrade (2009), Lohman (2009), Berg y Chyung (2008), y Cunningham y Hillier (2013). Se realizaron análisis estático descriptivo de dato cuantitativo, temático y categórico de las respuestas abiertas.

Síntesis de los principales resultados: Había cinco categorías de aprendizaje informal: las relaciones interpersonales; prácticas en el trabajo; el intercambio de conocimientos; formación sistemática y la categoría independiente. El aprendizaje informal depende de: 1. relaciones interpersonales, 2 . diseño de prácticas de trabajo, 3. intercambio de conocimientos y 4. autoeducación. Se consideraron algunos factores facilitadores y o inhibidores, y favorable y/o desfavorable.

Principales consideraciones/conclusiones: Los profesionales describen el aprendizaje informal como difícil de probar y que está ocurriendo por medio de la práctica y ejercicios de sus habilidades. Se sugiere para el 
trabajo futuro: 1. analizar la influencia de las variables ambientales sobre el uso de estrategias de aprendizaje informal; 2. relacionarse aprendizaje profesional con las iniciativas de gestión del conocimiento en la Agencia; y 3. observar el papel de liderazgo en el proceso de aprendizaje informal.

\section{PALABRAS CLAVE}

Aprendizaje informal. Sector público brasileño. Profesionales de las TIC. Tribunal superior militar. Estrategias de aprendizaje.

\section{REFERENCES}

Abbad, G., \& Borges-Andrade, J. E. (2004). Aprendizagem humana nas organizações e trabalho. In J. C. Zanelli, J. E. Borges-Andrade, \& A. V. B. Bastos (Orgs.), Psicologia, organizações e trabalho no Brasil (pp. 237-275). Porto Alegre: Artmed.

Alfieri, L., Brooks, P. J., Aldrich, N. J., \& Tenenbaum, H. R. (2011). Does discovery-based instruction enhance learning? Journal of Educational Psychology, $103(1), 1-18$.

Ang, S., \& Slaughter, S. (2000). The missing context of information technology personnel: a review and future directions for research. In R. W. Zmud (Ed.). Framing the domains of IT management: projecting the future from the past. Cincinatti: Pinnaflex Educational Resources.

Abreu, M. (2013). Valores dos trabalhadores da indústria brasileira de software e serviços de TI: contribuições para a gestão do conhecimento. Dissertação de mestrado em gestão do conhecimento e tecnologia da informação, Universidade Católica de Brasília, Brasília, DF, Brasil.

Antonello, C. S. (2011a). Contextos do saber: a aprendizagem informal. In C. S. Antonello \& A. S. Godoy (Orgs). Aprendizagem organizacional no Brasil (pp. 139-159). Porto Alegre: Bookman.

Antonello, C. S. (2011b). Saberes no singular? Em discussão a falsa fronteira entre aprendizagem formal e informal. In C. S. Antonello \& A. S. Godoy (Orgs). Aprendizagem organizacional no Brasil (pp. 225-245). Porto Alegre: Bookman.

Baker, A. C., Jensen, P. J., \& Kolb, D. A. (2005). Conversation as experiential learning. Management Learning, 36(4), 411-427. 
Bardin, L. (2011). Análise de conteúdo. São Paulo: Edições 70.

Barnett, K. (2012). Student interns' socially constructed work realities: narrowing the work expectation-reality gap. Business Communication Quarterly, 73(3), 271-290.

Berg, S. A., \& Chyung, S. Y. (2008). Factors that influence informal learning in the workplace. Journal of Workplace Learning, 20(4), 229-244.

Berings, M. G. M. C., Doornbos, A. J., \& Simons, P. R. (2006). Methodological practices in on-the-job learning research. Human Resource Development International, 9(3), 333-363.

Booth, A., Carroll, C., Papaioannou, D., Sutton, A., \& Wong, R. (2009). Applying findings from a systematic review of workplace-based e-learning: implications for health information professionals. Health Information \& Libraries Journal, 26 (1), 4-21.

Brandão, H. P., \& Borges-Andrade, J. E. (2011). Desenvolvimento e validação de uma escala de estratégias de aprendizagem no trabalho. Psicologia: Reflexão e Crítica, 24(3), 448-457.

Brandão, H. P., Borges-Andrade, J. E., Puente-Palácios, K., \& Laros, J. A. (2012). Relationships between learning, context and competency: a multilevel study. BAR - Brazilian Administration Review, 9(1), 1-22.

Brasil (2012). Ministério do Planejamento, Desenvolvimento e Gestão. Planejamento Estratégico - 2012-2015. Brasília, DF. Retrieved June 15, 2013, from http://www.planejamento.gov.br/secretarias/upload/Arquivos/publicacao/ planejamento_estrategico/130314_planejamento_estrategico.pdf.

Brasil (2013). Ministério do Planejamento, Desenvolvimento e Gestão. Programa Gespública, Modelo de Excelência do Sistema de Gestão Pública - Guia de inovação e melhoria do Sistema de Gestão da Administração Pública. Brasília, DF: MP, SEGEP.

Camillis, P. K., \& Antonello, C. S. (2010). Um estudo sobre os processos de aprendizagem dos trabalhadores que não exercem função gerencial. Revista de Administração Mackenzie, 11 (2), 4-42.

Casey, C. (2013). Learning organizations, learning workers: toward enhanced employment relations. International Journal of Continuing Education \& Lifelong Learning, 5(2), 121-137.

Chan, S. (2013). Learning through apprenticeship: belonging to a workplace, becoming, being. Vocations and Learning, 6(3), 367-383.

Coelho, Jr., F. A., \& Borges-Andrade, J. E. (2008). Uso do conceito de aprendizagem em estudos relacionados ao trabalho e organizações. Paidéia, 18(40), 221-234. 
Coelho, Jr., F. A., \& Mourão, L. (2011). Suporte à aprendizagem informal no trabalho: uma proposta de articulação conceitual. Revista de Administração Mackenzie, 12(6), 224-253.

Coelho, Jr., F. (2009). A. Suporte à Aprendizagem, satisfação no trabalho e desempenho: um estudo multinível. Brasília, DF: Universidade de Brasília. Retrieved February 19, 2017, from http://repositorio.unb.br/bitstream/ 10482/4691/3/2009_FranciscoAntonioCoelhoJunior.pdf.

Conlon, T. J. (2004). A review of informal learning literature, theory and implications for practice in developing global professional competence. Journal of European Industrial Training, 28(2/3/4), 283-295.

Conselho Nacional de Justiça. (2009). Resolução n. 70 de 18 de março de 2009. Dispõe sobre o Planejamento e a gestão estratégica no âmbito do poder judiciário e dá outras providências. Brasília, DF. Retrieved June 15, 2013, from http://www.cnj.jus.br/gestao-e-planejamento/gestao-e-planejamento-do-judiciario/planejamento-estrategico-do-poder-judiciario.

Crepeau, R. G., Crook, C. W., Goslar, M. D., \& Mcmurtrey, M. E. (1992). Career abchors of information systems personnel. Journal of Management Information Systems, 9(2), 145-160.

Cunningham, J., \& Hillier, E. (2013). Informal learning in the workplace: key activities and processes. Education + Training, 55(1), 37-51.

Decreto n. 5.378, de 23 de fevereiro de 2005. (2005). Institui o Programa Nacional de Gestão Pública e Desburocratização - Gespública e o Comitê Gestor do Programa Nacional de Gestão Pública e Desburocratização, e dá outras providências. Retrieved November 11, 2013, from http://www.planalto.gov.br/ccivil_03/_ato2004-2006/2005/decreto/d5378.htm.

De Grip, A. (2015). The importance of informal learning at work. Netherlands: Maastricht University.

Easterby-Smith, M., \& Araújo, L. (2001). Aprendizagem organizacional: oportunidades e debates atuais. In M. Easterby-Smith, J. Burgoyne \& L. Araújo (Coords.). Aprendizagem organizacional e organização de aprendizagem: desenvolvimento na teoria e na prática (pp. 15-38). São Paulo: Atlas.

Elkjaer, B. (2001). Em busca de uma teoria de aprendizagem social. In M. Easterby-Smith, J. Burgoyne \& L. Araujo (Coords.). Aprendizagem organizacional e organização de aprendizagem: desenvolvimento na teoria e na prática (pp. 100-118). São Paulo: Atlas.

Eraut, M. (2007). Learning from other people in the workplace. Oxford Review of Education, 33(4), 403-422. 
Fenwick, T. J. (2003). Reclaiming and re-embodying experiential learning through complexity science. Studies in the Education of Adults, 35(2), 123-141.

Fenwick, T. (2008). Understanding relations of individual-collective learning in work: a review of research. Management Learning, 39(3), 227-243.

García-Peñalvo, F. J., \& Conde, M. Á. (2014). Using informal learning for business decision making and knowledge management. Journal of Business Research, 67(5), 686-691. DOI: http://dx.doi.org/10.1016/j.jbusres.2013.11.028.

Hann, M., \& Caputo, S. M. (2012). Learning in the workplace: a literature review. New Brunswick: Department of Post-Secondary Education, Training and Labour.

Hew, K. F., \& Cheung, W. S. (2014). Students' and instructors' use of massive open online courses (MOOCs): motivations and challenges. Educational Research Review, 12(1), 45-58.

Hoffman, T. (2003). Job satisfaction survey: what's wrong here?. Computer World. Retrieved February 18, 2017, from http://www.computerworld.com/ article/2574043/it-careers/what-s-wrong-here-.html.

Holman, D., Epitropaki, O., \& Fernie, S. (2001). Understanding learning strategies in the workplace: a factor analytic investigation. Journal of Occupational and Organizational Psychology, 74(5), 675-681.

Huarng, A. S. (2001). Burnout syndrome among information system professionals. Information Systems Management, 18(2), 15-20.

Inanc, H., Zhou, Y., Gallie, D., Felstead, A., \& Green, F. (2015). Direct participation and employee learning at work. Work and Occupations, 42 (4), 447-475.

Isidro-Filho, A., Guimarães, T. A., Perin, M. G., \& Leung, R. (2013). Workplace learning strategies and professional competencies in innovation contexts in Brazilian hospitals. BAR - Brazilian Administration Review, 10(2), 121-134.

Jacobs, R. L., \& Park, Y. (2009). A proposed conceptual framework of workplace learning: Implications for theory development and research in human resource development. Human Resource Development Review, 8(2), 133-150.

Kolb, D. A. (1984). Experiential learning: experience as the source of learning and development. Englewood Cliffs: Prentice-Hall.

Le Clus, M. (2011). Informal learning in the workplace: a review of the literature. Australian Journal of Adult Learning, 51 (2), 355-373.

Lohman, M. C. (2009). A survey of factors influencing the engagement of information technology professionals in informal learning activities information technology. Learning, and Performance Journal, 25(1), 43-53. 
Mangia, U. B., \& Jóia, L. A. (2015). Antecedentes à transição de carreira dos profissionais de Tecnologia da Informação. Revista de Administração São Paulo, 50(4), 541-560.

Manuti, A., Pastore, S., Scardigno, A., Giancaspro, M. L., \& Morciano, D. (2015). Formal and informal learning in the workplace: A research review. International Journal of Training and Development, 19(1), 1-17.

Moura Jr., P. J., \& Helal, D. H. (2014). Profissionais e profissionalização em tecnologia da informação: indicativos de controvérsias e conflitos. Cadernos EBAPE.BR, 12 (2), 321-338.

Neiva, E. R., \& Pantoja, M. J. (2011). Aprendizagem e mudança organizacional: das relações entre atitudes frente à mudança e estratégias de aprendizagem no trabalho. Interamerican Journal of Psychology, 45(2), 145-155.

Noe, R., Clarke, A., \& Klein, H. (2014). Learning in the twenty-first-century workplace. Annual Review of Organizational Psychology and Organizational Behavior, 1 (1), 245-275.

Ono, M., \& Binder, M. P. (2010). Os sentidos do trabalho: estudo com profissionais de TI que trabalham por projeto. In Anais do $34^{\circ}$ Enanpad. Rio de Janeiro: Editora da Anpad.

Pantoja, M. J., \& Borges-Andrade, J. E. (2009). Estratégias de aprendizagem no trabalho em diferentes ocupações profissionais. Revista de Administração Contemporânea - RAC Eletrônica, 3(1), 41-62.

Ramos, E. A. A., \& Jóia, L. A. (2014). Uma investigação acerca do fenômeno do turn-away entre os profissionais de tecnologia da informação. Revista de Administração Mackenzie, 15(4), 75-109.

Roberts, J. (2008). From experience to neo-experiential education: variations on a theme. Journal of Experiential Education, 31 (1), 19-35.

Silva, E. L., \& Menezes, E. M. (2005). Metodologia da pesquisa e elaboração de dissertação. Florianópolis: Universidade Federal de Santa Catarina. Retrieved August 7, 2013, from http://tccbiblio.paginas.ufsc.br/files/2010/09/024_ Metodologia_de_pesquisa_e_elaboracao_de_teses_e_dissertacoes1.pdf.

Sonnentag, S., Niessen, C., \& Ohly, S. (2004). Learning at work: training and development. In C. L. Cooper \& I. T. Robertson (Orgs.). International Review of Industrial and Organizational Psychology (Vol. 19, pp. 249-289). London: John Wiley \& Sons.

Souza, P. C. A. R. (2016). Relação entre condições para criar e estratégias de aprendizagem no ambiente de trabalho. Dissertação de Mestrado em Administração, Universidade de Brasília, Brasília, DF, Brasil. 
Superior Tribunal Militar. (2011). (Brasil). Ato Normativo n. 12 de 2011. Guia de atribuições funcionais do Superior Tribunal Militar. Brasília, DF.

Superior Tribunal Militar (2012). (Brasil). Planejamento estratégico da justiça militar da União: 2012-2013. Brasília, DF.

Tomkins, L., \& Ulus, E. (2016). Oh, was that "experiential learning”?! Spaces, synergies and surprises with Kolb's learning cycle. Management Learning, 47(2), 158-178.

Tynjälä, P. (2008). Perspectives into learning at the workplace. Educational Research Review, 14(3), 130-154.

Wang, C. L., \& Ahmed, P. K. (2003). Organizational learning: a critical review. The Learning Organization, 10(1), 8-17.

Watkins, K. E., \& Marsick, V. J. (1992). Toward a theory of informal and incidental learning in organizations. International Journal of Lifelong Education, $11(4), 287-300$.

Zundel, M. (2012). Walking to learn: rethinking reflection for management learning. Management Learning, 44(2), 109-126. 